\title{
Preparation and Quality Evaluation of Processed Cheese Made from Different Cheeses and Paneer
}

\author{
UPENDRA POKHAREL ${ }^{1 *}$ and DIPENDRA KHANAL
}

\author{
Himalayan College of Agricultural Sciences and Technology (HICAST), Nepal
}

\begin{abstract}
Processed cheese (PC), a modified form of natural cheese was prepared mixing with different proportions of Cheese and Paneer; Yak cheese and Kanchan cheese (70:30), Yak and Kanchan (30:70), Kanchan and Mozzarella (75:25), Yak, Kanchan, Mozzarella and Paneer (30:45:15:10) and Kanchan and Paneer (85:15) with PC made in DDC, Nepal as a control. Five experimental products were subjected for sensory and physico-chemical analysis. The physico-chemical parameters of processed cheeses were significantly $(p<0.05)$ varied among each other products due to different combination of natural cheeses. The PC made from Yak and Kanchan cheese (30:70) was found to be superior $(p<0.05)$ in terms overall sensory attributes. From the results of physico-chemicals and sensory analysis it was concluded that PC made from Yak and Kanchan (30:70) was the best formulation among all.
\end{abstract}

Keywords: Processed cheese, Yak cheese, Kanchan cheese, Mozzarella, Paneer

\section{Introduction}

Processed cheese (PC) is prepared with the aid of heat by comminuting and blending one or more lots of shredded natural cheese with water, salt, color and suitable emulsifying agents into a homogeneous plastic mass, followed by heating the blend under a partial vacuum with a constant agitation until a homogeneous mass is obtained and then air cooling. If processing is performed discontinuously, i.e. in a doublejacketed kettle, the temperature reached is $71-95^{\circ} \mathrm{C}$ for a period of 4-15 min, depending on various parameters (Piska et al., 2004). It is made by further processing of finished cheese, usually a blend of hard rennet varieties with different aromas and degree of maturity for uniformity, safety, longer keeping quality and effective merchandising (NDRI, 2006). PC means the product obtained by heating cheese with permitted emulsifiers/stabilizers namely sodium citrate, sodium salts of orthophosphoric acid and polyphosphoric acid with or with out added condiments and acidifying agents, namely lactic acid, vinegar, phosphoric acid and citric acid, acetic acid (Fox, 1996). PC shall contain not more than $4.0 \%$ of permitted emulsifiers, and/or stabilizers. Similarly moisture should be not more than $47.0 \%$ and milk fat content should be not less than $40.0 \%$ of the dry matter. PC may contain $0.1 \%$ sorbic acid, or its sodium, potassium or calcium salts or $0.1 \%$ of nicin (NDRI, 2006).

The important varieties of cheese produced in Nepal are Yak cheese, Kanchan cheese and Mozzarella. Those cheese with possible defects during storage, ripening and transportation regarding surface, color, texture, size and shape as well as cheese with limited shelf-life can also be used for further processing. A PC with desirable characteristics can be made

\footnotetext{
*Corresponding author, E-mail: upendrapokharel@gmail.com ${ }^{1}$ Present address : Council for Technical Education and Vocational Training (CTEVT), Sanothimi, Bhaktapur, Nepal, P.O. Box 3546, Kathmandu
}

by blending together $55 \%$ non aged cheese, $35 \%$ medium aged cheese and $10 \%$ fully aged cheese (Kosikowski, 1977). The keeping quality of PC is better than those of ordinary cheese because enzymes and micro-organisms could be destroyed in the melting process. PC can be packaged in air tight and light proof materials such as cups and tubes or small aluminum foils or plastic parcels.

Therefore, this study aims to find out the optimum combination of different process cheeses to prepare a high quality processed cheese from easily available natural raw cheeses in Nepal.

\section{Materials and Methods}

The research was carried out at Dairy Development Corporation (DDC) Kathmandu, HICAST lab and in Livestock quality control lab, Hariharbhawan.

Raw materials: The raw materials used in making PC were all natural cheeses having matured more than 6 months for Yak cheese, 4 -5 months for Kanchan, below 1 month for Mozzarella and 15 days for Paneer. The raw cheeses were purchased by DDC. Disodium hydrogen phosphate and trisodium hydrogen phosphate were used as emulsifier. Sorbic acid and other ingredients e.g. water, salt, butter was locally purchased. All the chemicals were of analytical grade. The natural paneer was prepared by Paneer Utpadan Kendra, Nagarkot under DDC.

Product formulation: Five batches of processed cheeses were prepared in laboratory namely; $\mathrm{PC}_{1}=$ Kanchan and paneer (85:15), $\mathrm{PC}_{2}=$ Kanchan and Mozzarella (75:25), $\mathrm{PC}_{3}=$ Yak cheese and Kanchan (70: 30), $\mathrm{PC}_{4}=$ Yak cheese, Kanchan, Mozzarella and Paneer (30:45: 15: 10), $\mathrm{PC}_{5}=$ Yak cheese and Kanchan (30: 70) and a control was taken from the regular manufacturing processed cheese of DDC, Nepal. The formulation for each type of processed cheese is given in Table 1. 
Table1. Combinations of natural cheese for making experimental products

\begin{tabular}{ccccc}
\hline $\begin{array}{c}\text { Processed cheese } \\
\text { products }\end{array}$ & \multicolumn{4}{c}{ Natural cheese proportions (\%) } \\
\cline { 2 - 5 } & Yak cheese & Kanchan & Mozzarella & Paneer \\
\hline $\mathrm{PC}_{1}$ & - & 85 & - & 15 \\
$\mathrm{PC}_{2}$ & - & 75 & 25 & - \\
$\mathrm{PC}_{3}$ & 70 & 30 & - & - \\
$\mathrm{PC}_{4}$ & 30 & 45 & 15 & 10 \\
$\mathrm{PC}_{5}$ & 30 & 70 & - & - \\
\hline
\end{tabular}

Emulsifier; disodium hydrogen phosphate $(2.4 \%)$ and trisodium hydrogen phosphate $(0.36 \%)$ of natural cheese were used. Similarly the preservative; sorbic acid $(0.12 \%)$ and other ingredients water $(20 \%)$, salt $(0.46 \%)$ and butter $(3 \%)$ were used in all combinations.

Process for processed cheese making: The processed cheese was manufactured by using following flow diagram (Figure 1).

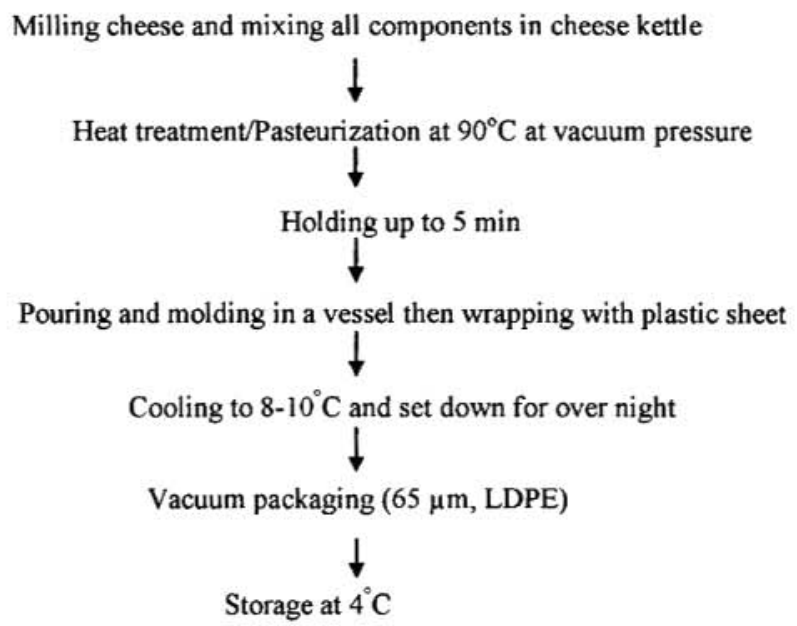

Figure 1. Flow chart for the manufacture of processed cheese

Natural cheeses were selected, cleaned the surface, trimmed, grounded and mixed the emulsifier as appropriate proportions to regulate the $\mathrm{pH}$ and to produce a stable product and maintaining its integrity during storage. The mixture of cheese was heated in cheese kettle up to $90^{\circ} \mathrm{C}$. The finished product was expected as 5.6-5.8 pH and containing about as much milk fat and moisture as did in the original natural cheese.

Five different combinations of processed cheese were manufactured as per the natural cheese ingredients (Table1). Those five experimental products were manufactured in single time and the samples of five treatments were analyzed in two replications.

Sampling and analysis: The samples were collected from each batch of products. All samples were kept in DDC cold store at $5-6^{\circ} \mathrm{C}$ until the analysis for physico-chemicals and sensory evaluation were done. All the samples were analyzed in triplicates.
Physico-chemical analysis: The fat content was determined by Gerber method and Moisture content was determined by using hot air oven method as described by Dairy Development Corporation, Quality Control Handbook (1989). The acidity was determined by titration as per the method described in NDRI, Laboratory Manual (2006). The $\mathrm{pH}$ was determined by using digital $\mathrm{pH}$ meter as described in Jayaram (1992). Salt was determined by using titration method as described in Laboratory Handbook for Dairy Industry (2001), NDDB. The protein was estimated by modified Micro-Kjeldahl method as described by Rangana (2001).

Sensory evaluation: Five combinations of experimental products of processed cheese and a control product were subjected for sensory evaluation by using 9-point hedonic scale as described by Rangana (2001). A semi-trained panel of 14 panelists from DDC was selected and the scoring for each sample was conducted on major sensory attributes viz. Texture, flavor, taste, color, and overall acceptability.

Statistical analysis: The data obtained from physico chemical tests and sensory evaluation was analyzed using SPSS (version 13.0) and MS Excel (version 2003). One way ANOVA was used for test statistics and LSD for mean separation by using SPSS (Version 11.5) at 95\% level of significance.

\section{Results and Discussion}

Physico-chemical parameters: The chemical analyses of processed cheese samples are shown in Table 2 and Figure 2. The product rating score was found to be in order of decreasing preference $\mathrm{PC}_{5}<\mathrm{PC}_{4}<\mathrm{PC}_{2}, \mathrm{PC}_{3}, \mathrm{PC}_{1}$ and control (Figure 2) for moisture. The average moisture content was found in the range of 42.50 to $44.5 \%$ in treatments and $49.4 \%$ in control. Except control all the results were within the Nepal standard as well as Indian standard (NDRI, 2006) of $47 \%$ moisture content. Since, the lowest the moisture content is believed higher the cheese quality (Byland, 1995). Therefore, $\mathrm{PC}_{5}$ is considered as best in respect of moisture content. Excessive moisture content might be due to the amount of addition of water in blend, agitating frequently in cooking time and increasing proportion of young cheese in blend etc.

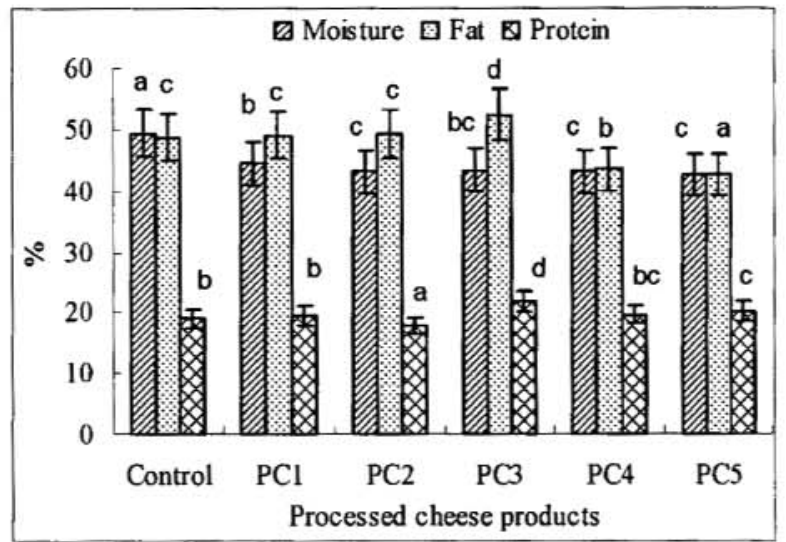

Figure 2. Moisture, fat and protein content in different processed cheese

Mean $\pm \mathrm{SD}$, Bars having different letters shows significant difference $(\mathrm{p}<0.05)$ 
The average fat content in samples were significantly varied $(\mathrm{p}<0.05)$ in the range of $42.50\left(\mathrm{PC}_{5}\right)$ to $52.38 \%\left(\mathrm{PC}_{3}\right)$, while $48.71 \%$ in control (Figure 2). The ANOVA showed that the protein content of prepared samples and control PC were sig. $(\mathrm{p}<0.05)$ difference (Figure 2$)$ within the products. The average protein content of samples ranged from $31.21 \%\left(\mathrm{PC}_{2}\right)$ to $38.36 \%\left(\mathrm{PC}_{3}\right)$, while $37.64 \%$ for control (Figure 2). The protein content was found to be higher in $\mathrm{PC}_{3}$. The ranking of the product Crude protein were $\mathrm{PC}_{3}<\mathrm{Control}<\mathrm{PC}_{5}<\mathrm{PC}_{1}<\mathrm{PC}_{4}<$ $\mathrm{PC}_{2}$. Protein content in PC should be above $44 \%$ (Fox, 1996). According to DDC standard for cheese, it should contain at least $22.80 \%$ protein in dry basis. But all prepared and control products were below the standards observed by Fox (1996), however the all samples complied the DDC standard.

Titrable acidity, $\mathrm{pH}$ and salt analysis result has been shown in (Table 2). The slight variation of acidity in processed cheese might be due to the different proportion of natural cheeses mixed in formula as well as due to lactic acid formed as a result of bacterial action on lactose of milk (De, 1996). The obtained results are in line with the finding of Krofa et al., (2004), as 0.17 to $0.25 \%$.

The $\mathrm{pH}$ for PC mentioned by Fox (1996) is 5.6-5.8. In control, $\mathrm{PC}_{1}$ and $\mathrm{PC}_{5}$ were little bit higher than the standard prescribed by Fox (1996), while the $\mathrm{pH}$ for $\mathrm{PC}_{2}, \mathrm{PC}_{3}$ and $\mathrm{PC}_{4}$ were within the range. The ANOVA revealed that the products were significantly $(\mathrm{p}<0.05)$ different within the groups (Table 2$)$.

According to National standard for common salt in processed cheese has been mentioned as $3 \%$. $\mathrm{PC}_{5}$ and control products showed slightly higher value than the National standard (Table2). Control sample and $\mathrm{PC}_{5}$ were not significantly $(\mathrm{p}<0.05)$ difference but all remaining samples were significantly $(\mathrm{p}<0.05)$ difference with those two samples. Salt content of all products were significantly $(p<0.05)$ different within the products except $\mathrm{PC}_{5}$ and control. Salt inhibits the growth of certain microorganisms (Mathur et al., 2005).

Sensory evaluation: $\mathrm{PC}_{5}$ of Yak cheese and Kanchan (30:70) were better in terms of texture, flavor and taste whereas the color and overall acceptance was higher in $\mathrm{PC}_{1}$ of Kanchan and paneer (85:15). The control product had lowest score in all sensory parameters (Table 3 ).

The texture, flavor, taste and overall acceptance were sig. different in various proportions products except color (Table 3 and Figure 3). It showed that the effects of treatments occurred in the variation of the proportion ingredients in texture, flavor, taste and overall attributes, but there was no effect of treatment in color. All the experimental products were significantly differed with control in term of texture, flavor, taste and overall acceptance except color. The off-flavor observed in milk fat was due to long time storage might cause oxidative rancidity on fat leading to the production of saturated and un-saturated aldehydes and also unsaturated ketenes and alcohols (Rao, 1996).

Preferences for texture was ranked as $\mathrm{PC}_{5}<\mathrm{PC}_{1}<\mathrm{PC}_{3}<\mathrm{PC}_{2}<$ $\mathrm{PC}_{4}<$ control (Figure 3 ). The texture was significantly higher $(\mathrm{p}<0.5)$ for control as compare to others. Flavor is an identifiable and distinctive quality of cheese perceived with the combined senses of taste or smell. The panels preferences was found as $\mathrm{PC}_{5}<\mathrm{PC}_{2}<\mathrm{PC}_{4}<\mathrm{PC}_{3}<\mathrm{PC}_{1}<$ control (Table 3) for flavor. Result for flavor score showed that the various processed cheese were significantly $(\mathrm{p}<0.05)$ different among the products. But between the products the control product was significantly $(\mathrm{p}<0.05)$ scored least as compared to all other products. $\mathrm{PC}_{5}$ with $\mathrm{PC}_{2}$ showed no significant $(\mathrm{p}<0.05)$ difference (Table 3 ) and having the higher preference in term of flavor among all.

Table 2. Chemical analysis of various product processed cheese

\begin{tabular}{lcccccc}
\hline \multirow{2}{*}{ Parameters* $^{*}$} & \multicolumn{5}{c}{ Products } \\
\cline { 2 - 7 } Control & PC1 & PC2 & PC3 & PC4 & PC5 \\
\hline Acidity (\%) & $0.27 \pm 0.06^{\mathrm{c}}$ & $0.25 \pm 0.71^{\mathrm{c}}$ & $0.25 \pm 0.71^{\mathrm{c}}$ & $0.28 \pm 0.00^{\mathrm{bc}}$ & $0.27 \pm 0.09^{\mathrm{bc}}$ & $0.31 \pm 0.71^{\mathrm{a}}$ \\
$\mathrm{pH}$ & $6.14 \pm 0.06^{\mathrm{a}}$ & $6.04 \pm 0.5^{\mathrm{ab}}$ & $5.65 \pm 0.71^{\mathrm{ac}}$ & $5.79 \pm 0.13^{\mathrm{bc}}$ & $5.70 \pm 0.14^{\mathrm{bc}}$ & $5.90 \pm 0.14^{\mathrm{c}}$ \\
Salt (\%) & $4.15 \pm 0.07^{\mathrm{a}}$ & $2.53 \pm 0.04^{\mathrm{c}}$ & $2.85 \pm 0.07^{\mathrm{b}}$ & $2.37 \pm 0.42^{\mathrm{d}}$ & $2.63 \pm 0.09^{\mathrm{c}}$ & $4.10 \pm 0.14^{\mathrm{a}}$ \\
\hline
\end{tabular}

$*$ Mean \pm S.D., different lowercase letters in superscripts (a-d) in the same row denotes the values are significantly different $(\mathrm{p}<0.05)$

Table 3. Analysis of sensory evaluation of various product processed cheese

\begin{tabular}{|c|c|c|c|c|c|c|}
\hline \multirow{2}{*}{$\begin{array}{l}\text { Test } \\
\text { Parameters* }\end{array}$} & \multicolumn{6}{|c|}{ Products } \\
\hline & Control & PC1 & PC2 & PC3 & PC4 & PC5 \\
\hline Flavor & $3.50 \pm 1.51^{\mathrm{a}}$ & $3.50 \pm 1.28^{\mathrm{b}}$ & $6.36 \pm 0.75^{\mathrm{c}}$ & $5.43 \pm 1.74^{\mathrm{bc}}$ & $5.57 \pm 1.79^{\mathrm{b}}$ & $7.07 \pm 1.07^{\mathrm{c}}$ \\
\hline Taste & $2.79 \pm 1.31^{\mathrm{a}}$ & $7.00 \pm 1.18^{\mathrm{d}}$ & $6.43 \pm 1.40^{\mathrm{d}}$ & $5.50 \pm 1.65^{\mathrm{bc}}$ & $5.07 \pm 1.82^{\mathrm{bc}}$ & $7.07 \pm 1.07^{\mathrm{d}}$ \\
\hline Color & $5.79 \pm 1.67^{\mathrm{a}}$ & $7.21 \pm 1.12^{b}$ & $6.29 \pm 1.64^{\mathrm{ab}}$ & $6.36 \pm 1.69^{\mathrm{ab}}$ & $6.21 \pm 1.85^{\mathrm{ab}}$ & $6.86 \pm 1.29^{\mathrm{ab}}$ \\
\hline $\begin{array}{l}\text { Overall } \\
\text { acceptance }\end{array}$ & $3.93 \pm 1.49^{\mathrm{a}}$ & $7.07 \pm 1.33^{\mathrm{c}}$ & $6.29 \pm 1.07^{\mathrm{bc}}$ & $5.43 \pm 1.70^{\mathrm{b}}$ & $5.57 \pm 1.79^{\mathrm{bc}}$ & $6.57 \pm 1.40^{\mathrm{c}}$ \\
\hline
\end{tabular}

\footnotetext{
$*$ Mean \pm S.D., values with different superscript letters $(a-d)$ in the same rows are significantly different $(p<0.05)$
} 


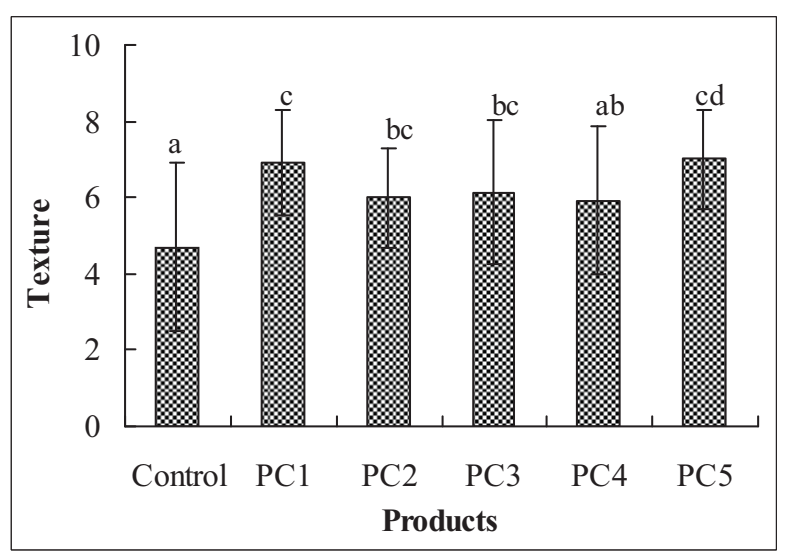

Figure 3. Bars showing texture of different processed cheese

Mean $\pm \mathrm{SD}$, Bars having different letters show significantly different $(\mathrm{p}<0.05)$

For the taste, the highest score was for sample $\mathrm{PC}_{5}$ followed by $\mathrm{PC}_{1}$, where as control product was least preferred (Table $3)$. The recipe did not influenced on the color of products significantly $(\mathrm{p}>0.05)$; however all were found significantly different than control one. The overall acceptability was found to be significant different $(\mathrm{p}<0.05)$ among the products but within the groups $\mathrm{PC}_{1}$ and $\mathrm{PC}_{5}$ obtained the highest insignificant score $(\mathrm{p}<0.05)$, while control was lest preferred. Considering all other attributes product PC5 could be recommended as the best product based on sensory qualities.

\section{Conclusion}

Based on the results, it has been concluded that the product $\mathrm{PC}_{5}$ [the combination of Yak cheese and Kanchan (30:70)] was found to be superior in physico-chemicals as well as sensory quality. The overall result revealed that still the best product has the various shortcomings to fully satisfy the consumer's needs; however, the product could meet the national and international standard for processed cheeses. Nevertheless, it is very important to consider the high quality of processed cheese could be produced only from high quality raw materials. Apparently, microbiological study as well as other flavor and natural toxin study on such product before commercialization seems to be beneficial for risk analysis.

\section{Acknowledgements}

The author expresses his sincere gratitude to Mr. Krishna Gopal Shrestha (General Manager), Mr. Siyaram P. Singh and Mr. Ishwori P. Adhikari for providing research requisites in DDC, Lainchaur. Author also acknowledges to Laboratory staff of DDC, DLS Hariharbhawan and HICAST for their cordial help while conducting the research.

\section{References}

Byland G. (1995). Dairy Processing Handbook, Tetrapak Processing Systems, Lund, Sweden.

Dairy Development Corporation, Quality Control Handbook (1989).

De S. (1996). Outlines of Dairy Technology, Oxford University Press Delhi.

Fox P. F. (1996). In Cheese: Chemistry, Physics and Microbiology, Vol. 2, Major Cheese Groups, Ed. P. F. Fox, Elsevier Applied Sci. Publishers, London.

Jayaram J. (1992).Laboratory Manual in Biochemistry, Wiley Eastern Ltd.

Kosikowski F.V. (1977). Cheese and Fermented Milk Foods. $2^{\text {nd }}$ edition, F.V. Kosikowski (Ed.) and Associates, New York, pp 282, 470 .

Krofa D., Reddy K. K., Reddy K. S. and Rao L.V. (2004). Effect of Certain Treatment on Quality of Cheese. M. V. Sc. Thesis, College of Veterinary Science, Hyderabad.

Laboratory Handbook for Dairy Industry (2001). National Dairy Development Board (NDDB), pp 160-179.

Mathur M. P., Roy D.D. and Dinakar P. (2005). Textbook of Dairy Chemistry.

National Dairy Research Institute- NDRI (2006). A Laboratory Manual, Karnal, Hydrabad, India.

Piska I. and Stejtina J. (2004). Influence of cheese ripening and rate of cooling of the processed cheese mixture on rheological properties of processed cheese. J. of Food Eng., 61:551-555.

Rangana S. (2001). Handbook of Analysis and Quality Control for Fruit and Vegetable Products, pp 594-644.

Rao Y. B. (1996). Influence of Raw Milk Quality Processing Temperature on Shelf-life of UHT Milk. Acharya N. G. Rao Agricultural University, Hyderabad, India. 